\title{
ACHONDROPLASIA AND PREGNANCY
}

Richa Sharma ${ }^{1}$, Arvind Kumar ${ }^{2}$

\section{HOW TO CITE THIS ARTICLE:}

Richa Sharma, Arvind Kumar. "Achondroplasia and Pregnancy". Journal of Evolution of Medical and Dental Sciences 2014; Vol. 3, Issue 16, April 21; Page: 4237-4240, DOI: 10.14260/jemds/2014/2424

ABSTRACT: Achondroplasia is a genetic disorder of bone growth occurring in 1:10, 000 to 1:40, 000 in all races and sexes. A 32 years old primigravida with achondroplasia at 31 weeks gestation presented to our gynae casualty with labor pain. LSCS was done in view of contracted pelvis. Baby also had achondroplasia and expired on $5^{\text {th }}$ neonatal day due to prematurity. Prenatal and preimplantational diagnostic tools are available regarding termination of pregnancy, rearing of affected child at home, foster care or adoption.

KEYWORDS: Achondroplasia, Pregnancy, Autosomal dominant

INTRODUCTION: Achondroplasia is a genetic disorder of bone growth occurring in 1:10, 000 to 1:40,000 in all races and sexes. ${ }^{1}$ This is most common group of growth disorder characterized by short stature with disproportionate short limbs.1,2 Because of rarity of this condition and its adverse impact on obstetrical outcome, we felt justifiable to report a case of Achondroplasia with pregnancy.

CASE REPORT: A 32 years old unbooked primigravida at 31 weeks gestation presented to our gynae casualty with history of show and labor pain. It was a spontaneous conception; her antenatal period was unsupervised although uneventful. She was disproportionate dwarf with height of 44 inch, upper span 30 inch, lower span 14 inch, arm span 35 inch and her weight was 48 kgs (Fig. 1). Age of her husband was 36 years and the height was $5 \mathrm{ft} 5$ inches. Abdominal examination revealed fundal height of 30 wks., cephalic presentation with good contractions and fetal heart sound was 132/min regular. PV examination indicated advanced labor and contracted pelvis, LSCS was done and $1.08 \mathrm{kgs}$ male baby was delivered with APGAR of $4 \& 6$ at $1 \mathrm{~min}$ and 5 min respectively. Baby had relatively large head circumference, normal length of trunk, short limbs and broad hands and feet (rhizomelic) appearance which is pathognomic of achondroplasia. Baby expired on $3^{\text {rd }}$ neonatal day due to prematurity and very low birth weight. Mother was discharged on $5^{\text {th }}$ post-op day after complete evaluation and genetic counseling.

Maternal growth hormone, thyroid function test and x-rays were done. GH $=1.17 \mathrm{ug}$ (normal), TFT (N), X-rays - Skull showed relatively large calvaria, prominent forehead, depressed nasal bridge, small skull base and foramen magnum (Fig. 2). Limbs x-ray indicated markedly shortened humeri (Fig. 3), short femoral neck (Fig. 4) and disproportionately long fibula in relation to tibia (Fig. 5). Spine X- ray (Fig. 6) showed caudal narrowing of interpedicular distances in lower lumbar spine and different degree of anterior wedging of vertebral bodies causing gibbus. Diagnosis of achondroplasia was made.

DISCUSSION: Achondroplasia is inherited as autosomal dominant trait with complete penetrance, caused by mutation in a gene Fibroblast growth factor receptor 3 (FGR3) located on ch locus 4p16.3. Mutation leads to increased tyrosine kinase activity in the cartilaginous growth plate, thus inhibiting bone growth. ${ }^{3}$ All bones that are formed by endocondral ossification are affected but bones that are 


\section{CASE REPORT}

formed by membrane ossification are not affected, thus allowing the skull vault to develop normally.4,5 More than $80 \%$ of the cases are not inherited but results from a new de novo dominant mutation that occurs in egg or sperm cell that form the embryo and its mutation rate is estimated to be 0.000014 per gamete per generation.2,5 Risk of recurrence in a family with sporadic cases is 1:443.Parents of achondroplasic child resulting from a new mutation are of normal height and chances of having second child affected is $<1 \% .6,7$ If one of the parent is affected then the risk of recurrence in offspring is $50 \%$ for either sex.

Advanced paternal age of more than 35 yrs. strongly correlates with achondroplasia. ${ }^{8}$ Affected people are at risk of corticomedullary compression, spinal stenosis, obesity and obstructive sleep problems.

They have increased incidence of menstrual complaints, leiomyomata and premature menopause. Decreased fertility and problems with certain contraceptions. Delivery should almost always by caesarean section under GA. ${ }^{9}$ Obstetric Problems encountered are preeclampsia, polyhydramnios, respiratory compromise, contracted pelvis requiring LSCS, prematurity and fetal wastage. Increased neonatal mortality due to hydrocephalus and thoracic cage abnormality.

Prenatal diagnosis: In high risk pregnancy prenatal diagnosis is possible by analysis of DNA for FGRF3 gene mutation of the fetal cells obtained by chorionic villus sampling (CVS) AT 10-12 wks. and by amniocentesis at 15-18 wks. ${ }^{10}$ Preliminary evidence suggest that diagnosis may be possible by detection of FGFR3 mutation in fetal DNA in maternal serum. ${ }^{11}$

In low risk pregnancy level-II ultrasound may identify short fetal limbs. Krakow et al (2003) described the use of 3D USG at 16-18wks to identify facial features and relative proportions of appendicular skeleton and limbs. Ruano et al (2004) used 3D USG and intrauterine 3D helical computer tomography (3D HCT) to enhance diagnostic accuracy for skeletal defects. ${ }^{12}$

Preimplantation genetic diagnosis (PGD) may be an option for some families in which disease causing mutation has been identified.

CONCLUSION: Affected individual (heterozygous) have 50\% risk of transmitting the disorder to their offspring, like our case. Prenatal diagnostic tools are available and the obstetrician should explore the options available to the family for the management of such fetus using non directive approach which includes discussion of pregnancy termination as well as continuation and rearing of affected child at home, foster care or adoption.

\section{REFERENCES:}

1. Stoll C, Dott B, Roth MP, Alembic Y. Birth prevalence rates of skeletal dysplasias. Clin Genet 1989; 35:88-92.

2. Trotter TL, Hall JG. The American academy of Pediatrics committee on genetics: Health supervision for children with achondroplasia. Pediatrics 2005; 116:771-783.

3. Ornith DM, Marie PJ. FGF signalling pathways in achondroplasia and intramembrane bone development and human genetic disease. Genes Dev 2002; 16:446-1465.

4. Rousseau F, Bonaventre J Legeai-Munnich A, Le Merrer M. Mutations in the gene encoding fibroblast growth factor receptor 3 in achondroplasia. Nature 1994; 371:252-254. 


\section{CASE REPORT}

5. Shiang R, Thompson LM, Zhu YZ, Church DM, Fielder TJ, Bocian M, Winokur ST, Wasmuth JJ. Mutations in the transmembrane domain of FGFR3 cause the most common genetic form of dwarfism, achondroplasia. Cell 1994; 78(2):335-42.

6. Horton WA, Hall JG, Hacht JT. Achondroplasia. Lancet 2007; 370:162-172.

7. Metter G, Fraser FC. Recurrence risk for sibs children with sporadic achondroplasia. Am J Med Genet 2000; 90:250-251.

8. Horton WA. Molecular pathogenesis of achondroplasia growth. Genet Horm 2006;22:49-54.

9. Allanson JE, Hall JG. Obstetric and gynecologic problems in women with chondrodystrophies. Obstet Gynecol 1986;67(1):74-8.

10. Bellus GA, Escallon CS, Ortiz de Luna R, Shumway JB, Blakemore KJ, McIntosh I, Francomano CA. First-trimester prenatal diagnosis in couple at risk for homozygous achondroplasia. Lancet 1994;344(8935):1511-2.

11. Chitty LS, Griffin DR, Meaney C, Barrett A, Khalil A, Pajkrt E, Cole TJ. New aids for the noninvasive prenatal diagnosis of achondroplasia: dysmorphic features, charts of fetal size and molecular confirmation using cell-free fetal DNA in maternal plasma. Ultrasound Obstet Gynecol 2011;37(3):283-9.

12. Ruano R, Molho M, Roume J, Ville Y. Prenatal diagnosis of fetal skeletal dysplasias by combining two-dimensional and three-dimensional ultrasound and intrauterine three-dimensional helical computer tomography. Ultrasound Obstet Gynecol 2004;24(2):134-40.

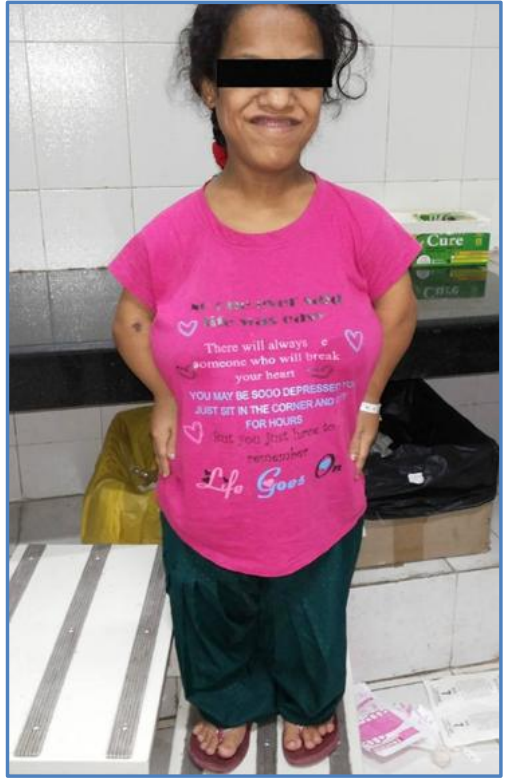

Fig. 1: Clinical photograph of the patient

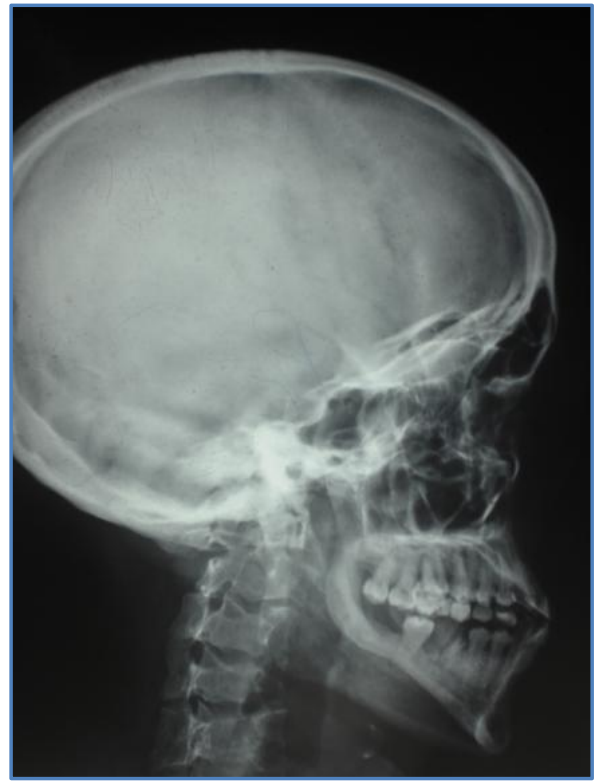

Fig. 2: X-ray skull 


\section{CASE REPORT}

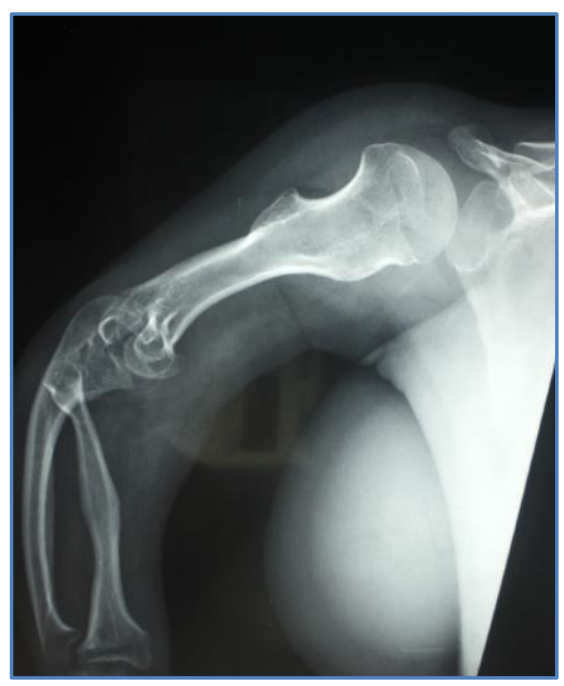

Fig. 3: X-ray showing upper limb

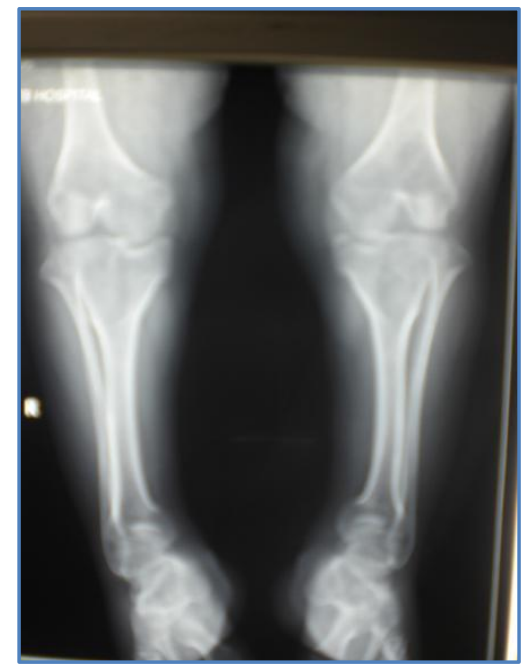

Fig. 5: X-ray showing lower limb

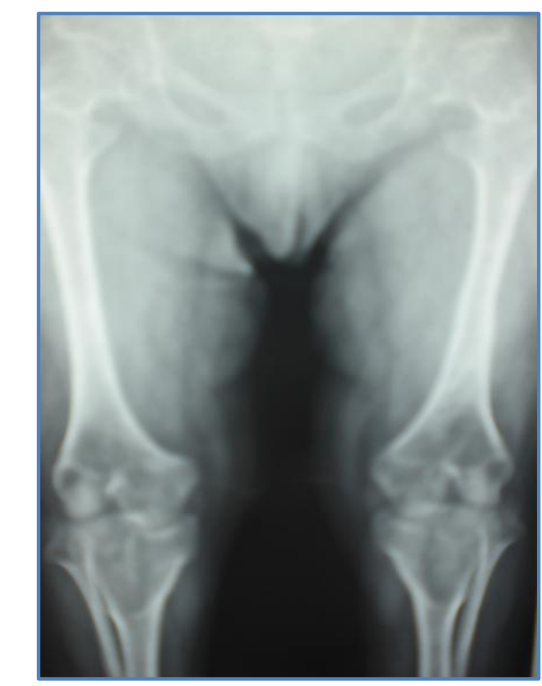

Fig. 4: X-ray showing lower limb

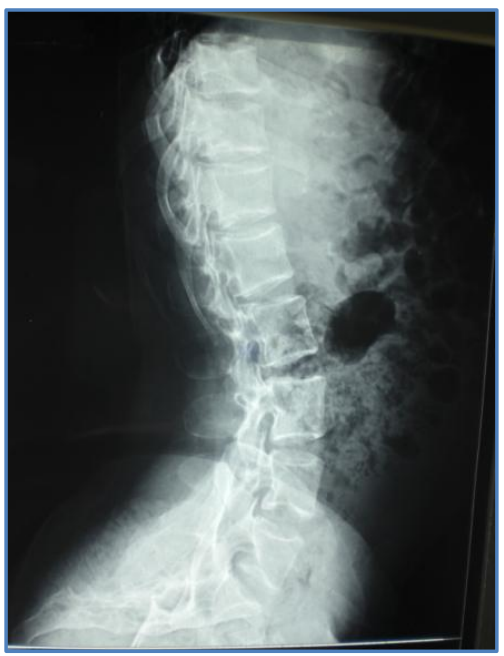

Fig. 6: X-ray spine

\section{AUTHORS:}

1. Richa Sharma

2. Arvind Kumar

\section{PARTICULARS OF CONTRIBUTORS:}

1. Assistant Professor, Department of Obstetrics and Gynaecology, University College of Medical Sciences and Guru Teg Bahadur Hospital, Delhi, India.

2. Assistant Professor, Department of Medicine, LLRM Medical College, Meerut, U.P, India.

\section{NAME ADDRESS EMAIL ID OF THE CORRESPONDING AUTHOR:}

Dr. Richa Sharma,

206, Kanchanjunga,

Kaushambhi, Ghaziabad,

Uttar Pradesh, India.

E-mail: gautamdrricha1@gmail.com

Date of Submission: 22/03/2014.

Date of Peer Review: 24/03/2014.

Date of Acceptance: 04/04/2014.

Date of Publishing: 16/04/2014. 